\title{
BACTÉRIAS COLIFORMES TOTAIS E COLIFORMES DE ORIGEMI FECAL EM ÁGUAS USADAS NA DESSEDENTAÇÃO DE ANIMAIS *
}

\author{
Luiz Carlos Souza** \\ Sebastião Timo Iaria *** \\ Gil Vianna Paim **** \\ Carlos Alberto Magalhães Lopes*****
}

\begin{abstract}
SOUZA, L, C. et al. Bactérias culiformes totais e coliformes de origem fecal em águas usadas na dessedentação de animais. Rev. Saúde públ., S. Paulo, 17:112-22, 1983.

RESUMO: Foram colhidas 105 amostras de água sendo 44 de mananciais e de 51 bebedouros, a partir das quais foram realizadas as determinações dos NMP (Número Mais Provável) de bactérias coliformes totais e fecais. De acordo com a Portaria GM/0013 de 15 de janeiro de 1976, da Secretaria Especial do Meio Ambiente do Ministério do Interior, os 44 mananciais revelaram-se dentro dos parâmetros estabelecidos. Embora não haja referência com relação a bebedouros, aplicando-se os valores estabelecidos para mananciais, das 61 amostras estudadas, somente $6(9,8 \%)$ não poderiam ser usadas para a dessedentação de animais. Das 105 amostras analisadas, verificou-se que as condições sanitárias revelaram-se não satisfatórias em $6(5,7 \%)$ amostras de bebedouros quanto a coliformes fecais, sendo $3(2,8 \%)$ também com relação a coliformes totais.
\end{abstract}

UNITERMOS: Āgua, condições sanitárias. Bebedouros, animais. Coliformes. Colifornes fecais.

\section{INTRODUTCYAO}

Como a àgua é um elemento imprescindivel à vida animal, é necessário que se adotem medidas para garantir, tanto quanto possivel, suas características, a fim de que seja própria ao consumo.
É sabido que as necessidades dos animais, relativamente ao consumo de água, variam com a espécie, tipo de criação, alojamento, condições do ambiente, natureza da dieta e temperatura (Templeton 26, 1968; Dikstra 12, 1970 e Manual Merck ${ }^{18}, 1970$ ).

* Extrafdo da Dissertação de Mestrado apresentada à Faculdade de Saúde Pública da USP, 1978, por Luiz Carlos de Souza, subordinada ao título "Determinação do NMP (Número Mais Provável) de bactérias coliformes e de coliformes fecais em águas usadas na dessedentação de animais em propriedades da região de Botucatu, Estado de São Paulo, 1974/75".

* Do Departamento de Higiene Veterinária e Saúde Pública da Faculdade de Medicina Veterinária e Zootecnia da UNESP, Campus de Botucatu - 18600 - Botucatt:, SP Brasil.

*** Do Departamento de Microbiologia e Imunologia do Instituto de Ciências Biomédicas da USP "Setor Saúde Pública" - Laboratóriode Microbiologia de Alimentos - Av. Dr. Arnaldo, 715 - 01255 - São Paulo, SP - Brasil.

**** Do Departamento de Prática de Saúde Pública da Facrildade de Saúde Pública da USP Av. Dr. Arnaldo, 715 - 01255 - São Paulo, SP - Brasil.

***** Do Departamento de Microbiologia e Imunologia do Instituto Básico de Biologia Médica e Agricola da UNESP. Campus de Botucatu - 18600 - Botucatu, SP - Brasil. 
Deve-se levar em conta, também, que ao se eleger um tipo de exploração pecuária, além de serem estudadas as possibilidades de destinação adequada de águas residuárias e excretas, deverá ser estabelecido também se $o$ abastecimento de água é suficiente em quantidade e qualidade.

A ausência de controle da qualidade da água deve conduzir, fatalmente, a curto ou a longo prazo, a infecçōes e envenenamentos, que podem ter conseqüências imprevisiveis para o desenvolvimento do local de criação (Von Der AA 28, 1971).

A água destinada ao consumo humano e animal deve ser isenta de contaminantes químicos e biológicos, além de apresentar certos requisitos de ordem estética. Entre os contaminantes biológicos são citados organismos patogênicos compreendendo bactérias, vírus, protozoários e helmintos, que veiculados pela água podem, através da sua ingestão, parasitar o organismo humano ou animal (Branco $\left.{ }^{5}, 1974\right)$.

As doenças transmissiveis que ocorrem nos animais domésticos, principalmente em bovinos, suínos e aves, representam fatores importantes à Economia e à Saúde Pública, pois podem acarretar prejuizos econômicos, às vezes elevados, e muitos dos seus agentes causais podem ser transmitidos ao homem.

Segundo Diesch 11 (1970), tem aumentado o interesse pela reavaliação do papel desempenhado pela água na transmissão de agentes causais de zoonoses, sendo tal fato devido à escassez de estudos com a finalidade de determinar as fontes de infecção. Porém, há casos registrados de doenças infecciosas de origem animal no homem e nos animais, relacionados à transmissão pela água e, principalmente, associadas a agentes bacterianos. Por outro lado, é pouco conhecido o papel da água como veículo de transmissão de vírus e outros agentes provenientes dos animais.

Podem ser veiculados pela água os agentes de muitas das doenças de animais, tais como: carbúnculo, salmoneloses, leptos- piroses, brucelose, tifo aviário, paratifo dos bezerros, colibacilose, tuberculose, erisipelóide, febre aftosa, peste suina, peste aviária, anemia infecciosa equina, cinomose, panleucopenia felina, peste suina africana, eimeriose e helmintíases (Hipólito e Freitas ${ }^{16}$, 1963; Blood e Henderson ${ }^{3}, 1969$; Dikstra ${ }^{12}$, 1970 e Merchant e Parker ${ }^{20}, 1970$.

Schwabe 25 (1969) refere que muitos tipos de virus foram identificados a partir de excreta humano $e$, também, um grande número a partir de fezes de animais, e que os métodos de tratamento de água podem não inativar todos os vírus.

Alguns estudos relativos à freqüência de isolamentos, por exemplo, de salmonelas, a partir de animais domésticos e de alimentos de origem animal realizados em nosso meio, mostram a importância desses agentes em Saúde Pública (Pestana e Rugai 22, 1943; Assumpção *, 1946; Jaria e col.17, 1965 e Giorgi 15, 1972).

$\mathrm{Na}$ verificação das condições sanitárias de águas de abastecimento, dadas as dificuldades no isolamento e identificação de organismos patogênicos, dá-se preferência, geralmente, a métodos que permitem a identificação e avaliação quantitativa de bactérias que, por serem habitantes normais do intestino de animais de sangue quente, existam, obrigatoriamente, em águas que receberam poluição fecal 1 .

Os coliformes têm sido úteis para medir a ocorrência e grau de poluição fecal em águas há, aproximadamente, 70 anos. Durante este tempo, acumulou-se grande número de dados que permitem avaliação da sensibilidade e especificidade de tal indicador bacteriano da presença de poluição de origem fecal. Por outro lado, os coliformes fecais, um sub-grupo dos coliformes, dão uma correlação direta da poluição por fezes de animais de sangue quente. A principal característica bioquímica usada para identificar os coliformes fecais é a sua capacidade de fermentar a lactose, com produção de gás, na temperatura de $44,5^{\circ} \mathrm{C}$. $\mathrm{O}$ exame de fezes de animais de sangue 
SOUZA, L.C. et al. Bacterias coliformes totais e coliformes de origem fecal em águas usadas na degsedentação de animais. Rev. Saúde públ., S. Paulo, 17:112-22, 1983.

quente, incluindo bovinos, suínos, ovinos, aves domésticas, cães, gatos e roedores, indica que os coliformes fecais contribuem com $93,0 \%$ a $98,7 \%$ do total de coliformes (Geldreich 13,1*, 1974).

Em águas de irrigação de hortas, Christovāo e col.7 (1967), no Município de São Paulo, observaram a presença de grau considerável de poluição fecal, através da determinação do NMP de bactérias coliformes e de Escherichia coli e, em outro estudo ${ }^{8}$, isolaram, dessas mesmas amostras de água, cepas de vírus entéricos ${ }^{8}$. No municipio de Ribeirão Preto, Estado de São Paulo, em amostras de água usadas na irrigação de hortaliças foi constatada a presença de enteroparasitas (Marzochi 19, 1970), assim como de altos graus de poluição de origem fecal (Costa e col.9, 1972 e Satake e col.24, 1976).

Mas, há em nosso meio número reduzido de estudos quanto à qualidade das águas usadas na dessedentação de animais relacionados a nascentes, poços, córregos, rios e lagoas, porém não há referências quanto a águas de bebedouros. Moreira e col.21 (1973), estudaram as condições sanitárias de águas utilizadas em granjas leiteiras em Santa Maria, Rio Grande do Sul, as quais foram colhidas de mananciais e de poços. Em outra pesquisa, em granjas avicolas no Estado de Minas Gerais, Vianna e col.27 (1975), examinando 80 amostras de água provenientes de poços, nascentes, córregos, rios e lagos, obtiveram resultados desfavoráveis quanto às suas condições sanitárias.

Tendo em vista o exposto, resolveu-se realizar a presente pesquisa, levando-se em conta não só os mananciais como também os bebedouros, para se ter uma idéia geral das condições de águas utilizadas na dessedentação de animais em propriedades de criação, situadas na região de Botucatu, Estado de São Paulo. Esta verificação foi feita através da determinação do NMP de coliformes totais e fecais e comparando-se os valores obtidos com os estabelecidos no Padrão Nacional vigente ${ }^{23}$.

\section{MATERIAL E METODOS}

Foram colhidas amostras de água de mananciais e de bebedouros, utilizada na dessedentação de animais de criação instaladas na região de Botucatu, Estado de São Paulo.

A colheita das amostras de água e o exame bacteriológico foram feitos de acordo com as técnicas padrões da Associação Americana de Saúde Pública I (1971).

Procedência das amostras - As amostras de água provieram de 25 propriedades, sorteadas de um total de 74 , por processo de amostragem probabilistica simples, sendo 13 localizadas no Município de Botucatu, 7 no de Pardinho e 5 no de Itatinga.

Foram colhidas amostras de 44 mananciais (M) e de 61 bebedouros (B), sendo de Botucatu $18 \mathrm{M}$ e $29 \mathrm{~B}$, de Pardinho $16 \mathrm{M}$ e $19 \mathrm{~B}$ e de Itating a $10 \mathrm{M}$ e $13 \mathrm{~B}$.

Colheita das amostras - As amostras de água foram colhidas no periodo de 2 de de julho de 1974 a 17 de fevereiro de 1975 . De cada um dos mananciais e bebedouros das propriedades pesquisadas, foram colhidos $100 \mathrm{ml}$ de água em frascos de vidro com tampa esmerilhada, com capacidade de $250 \mathrm{ml}$, esterilizados.

Relativamente aos mananciais, as amostras de água foram colhidas no local da nascente $\mathrm{e}$ as dos bebedouros foram obtidas diretamente nos locais onde os animais bebiam a água.

Transporte das amostras - Após a colheita das amostras, os frascos foram transportados ao laboratório em caixas isotérmicas (isopor) contendo cubos de gelo e aí mantidos até o início do exame. $O$ periodo decorrido entre a colheita das amostras de água e o inicio dos exames foi, no máximo, de quatro horas.

Informações obtidas nos estabelecimentos de criação de animais - Antes da colheita das amostras obtiveram-se, por meio de entrevista com o responsável pelo estabelecimento e/ou da observação, algumas informações a seguir relacionadas. 
SOUZA, L.C. et al. Bactérias coliformes totais e coliformes de origem fecal em águas usadas na dessedentação de animais. Rev. Saúde pübl., S. Paulo, 17:112-22, 1983.

a) Origem da água usada na dessedentação dos animais - de nascente ou de outro tipo de manancial e localização.

b) Fornecimento de água aos animais realizado por meio de bebedouros e qual o tipo, ou se diretamente do manancial.

c) Tipo de bebedouro e sua proteção estas constatações foram feitas através da observação e consideravam-se protegidos os bebedouros situados a certa altura do solo, de modo que a sua contaminação não se processasse com facilidade.

d) Número de animais abastecidos - um total de 4.496 animais, sendo 1.481 bovinos e 23 equinos (Botucatu), 1.770 bovinos e 12 suinos (Pardinho) e 1.710 bovinos (Itatinga).

Exame bacteriológico - A partir de cada uma das 105 amostras de água de mananciais e bebedouros foram determinados os NMP (Número Mais Provável) de bactérias dos grupos coliforme e coliforme de origem fecal, empregando-se técnicas dos inétodos padrōes adotados pela American Public Health Association 1 (1971).

Preparo das diluições - As amostras de água foram diluidas de $10^{-1}$ a $10^{-1}$, usando-se como diluente a água fosfatada com $\mathrm{pH} \mathrm{7,2}$ e esterilizada.

Determinação do NMP de coliformes - $\mathrm{Na}$ prova presuntiva foram inoculados com 10 $\mathrm{ml}$ e $1 \mathrm{ml}$ de água não diluída, respectivamente, em 5 tubos com caldo lactosado (Difco) com tubo de Durham. Das diluiçōes $10^{-1}$ a $10^{-4}$, foram também inoculados, com $1 \mathrm{ml}$ cada, respectivamente, 5 tubos de caldo lactosado com tubo de Durham. Todos os tubos foram incubados a $35^{\circ} \mathrm{C}$. As leituras foram realizadas após 24 e $48 \mathrm{~h}$, e a partir dos tubos com produção de gás procedia-se a prova confirmatória. Nesta prova, realizava-se a semeadura na superfície de ágar eosina - azul de metileno (Difco) em placas de Petri. Após a incubação a $35^{\circ} \mathrm{C}$ por $24 \mathrm{~h}$, considerava-se a prova positiva, quando desenvolviam-se colônias com as características das de coliformes, ou seja, totalmente negras, chatas, com brilho metálico ou claras, convexas, mucóides e com centro negro.

$\mathrm{Na}$ prova completa, isolava-se de cada placa uma colônia suspeita, a qual era semeada em um tubo contendo caldo lactosado com tubo de Durham e em outro com ágar simples inclinado. A prova era positiva quando após 24 a $48 \mathrm{~h}$, a $35^{\circ} \mathrm{C}$ ocorria produção de gás no tubo de caldo lactosado e crescimento de bacilos Gram-negativos obsevados em esfregaço corado pelo método de Gram, preparados a partir da cultura em ágar simples inclinado. A seguir, verificava-se o número de porções positivas $\mathrm{e}$ deteminava-se o NMP de coliformes por 100 $\mathrm{ml}$ de água, usando-se a tabela de Hoskins ${ }^{1}$.

Determinação do NMP de coliformes fecais - A partir dos tubos de caldo lactosado com produção de gás na prova presuntiva, eram realizadas semeaduras em caldo $\mathrm{EC}$ (Difco), usando-se alça de niquel-cromo, com $3 \mathrm{~mm}$ de diâmetro. Os tubos eram incubados em banho-maria a $44,5^{\circ} \mathrm{C}$ durante $24 \mathrm{~h}$. Consideravam-se como positivos para coliformes fecais, os tubos de caldo EC que revelavam produção de gás após a incubação. A partir das porçōes positivas e empregando-se a tabela de Hoskins ${ }^{1}$, determinava-se o NMP de coliformes fecais por $100 \mathrm{ml}$ da amostra.

\section{RHSULTADOS}

$\mathrm{Na}$ Tabela 1 estão distribuidos os resultados relativos às determinações dos NMP de coliformes totais e fecais por $100 \mathrm{ml}$ de água. Para coliformes totais, das 105 amostras examinadas, $3(2,8 \%)$ dos bebedouros apresentaram-se com NMP acima de 20.000/ $/ 100 \mathrm{ml}$, e para coliformes fecais $6(5,7 \%)$ dos bebedouros revelaram-se com NMP superior a $4.000 / 100 \mathrm{ml}$.

A Tabela 2 mostra, em relação a mananciais e bebedouros, a variação dos NMP de coliformes e coliformes fecais, segundo os municípios visitados. 
T A B E L A 1

NMP, por $100 \mathrm{ml}$, de coliformes totais e coliformes fecais em águas de dessedentação de animais em propriedades de criação da região de Botucatu, São Paulo, 1974/75.

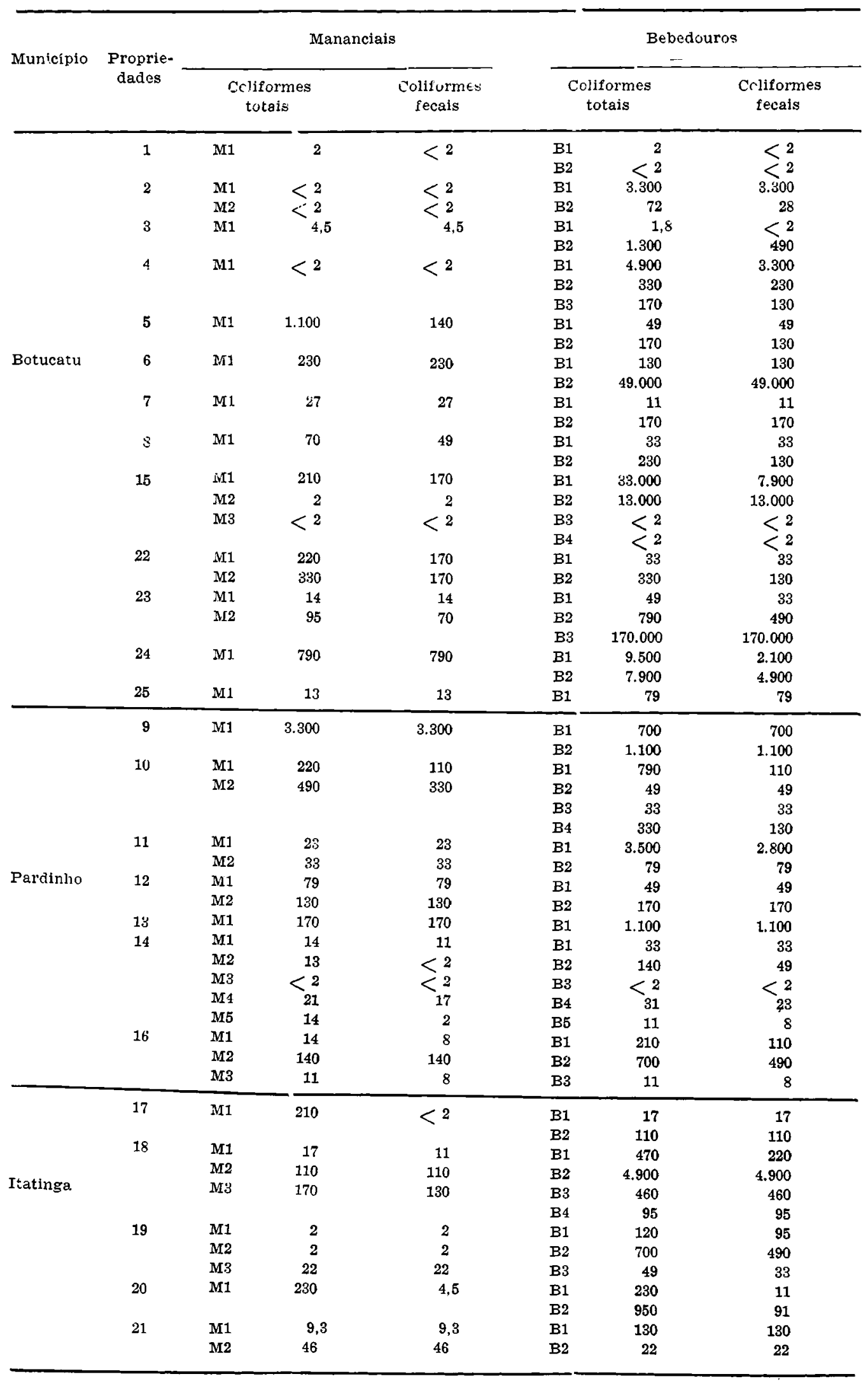


SoUZA, L.C. et al. Bactérias coliformes totais e coliformes de origem fecal em águas usadas na dessedentação de animais. Rev. Saúde pübl,. S. Paulo, 17:112-22, 1983.

\section{T A B E L A 2}

Amplitude de variação do NMP $/ 100 \mathrm{ml}$ de colfformes e coliformes fecais para águas de mananciais e bebedouros, segundo os municípios visitados da região de Botucatu, São Paulo, 1974/75.

\begin{tabular}{|c|c|c|c|c|c|c|}
\hline \multirow{4}{*}{$\begin{array}{l}\text { Municipio } \\
\text { Botucatu }\end{array}$} & \multicolumn{6}{|c|}{$\mathrm{NMP} / 100 \mathrm{ml}$} \\
\hline & \multicolumn{4}{|c|}{ Mananciais } & \multicolumn{2}{|c|}{ Bebedouros } \\
\hline & \multicolumn{2}{|c|}{ Coliformes } & \multicolumn{2}{|c|}{$\begin{array}{l}\text { Coliformes } \\
\text { fecais }\end{array}$} & Coliformes & $\begin{array}{c}\text { Coliformes } \\
\text { feorais }\end{array}$ \\
\hline & $<2$ a & 1.100 & $<2 a$ & 790 & $<2$ a 170.000 & $<2$ a 170.000 \\
\hline Pardinho & $<2 a$ & 3.300 & $<2 a$ & 3.300 & $<2$ a $\quad 3.500$ & $<2$ a $\quad 2.800$ \\
\hline Itatinga & $2 a$ & 230 & $<2 a$ & 130 & 17 a 4.900 & $11 \mathrm{a} \quad 4.900$ \\
\hline Total & $<2$ a & 3.300 & $<2 a$ & 3.300 & $<2$ a 170.000 & $<2$ a 170.000 \\
\hline
\end{tabular}

T A $\mathbf{B}$ E

Médias aritmética e geométrica e mediana dos NMP $/ 100 \mathrm{ml}$ de coliformes e coliformes fecais, para águas de mananciais e bebedouros, segundo os municípios visitados da região de Botucatu. São Paulo, $1974 \sqrt{75}$.

\begin{tabular}{|c|c|c|c|c|}
\hline \multirow{2}{*}{ Município } & \multirow{2}{*}{$\begin{array}{l}\text { Números } \\
\text { médios }\end{array}$} & \multirow{2}{*}{$\begin{array}{l}\text { Procedência } \\
\text { das amostras }\end{array}$} & \multicolumn{2}{|c|}{$\mathrm{NMP} / 100 \mathrm{ml}$} \\
\hline & & & Coliformes & $\begin{array}{c}\text { Coliformes } \\
\text { fecais }\end{array}$ \\
\hline Botucatu & $\begin{array}{l}\text { Ma. } \\
\text { Mg. } \\
\text { Me. }\end{array}$ & $\begin{array}{l}\text { Mananciais } \\
\text { Bebedouros } \\
\text { Mananciais } \\
\text { Bebedouros } \\
\text { Mananciais } \\
\text { Bebedouros }\end{array}$ & $\begin{array}{r}<172,6 \\
<10.156,9 \\
<2,2 \\
<21,5 \\
20,5 \\
170,0\end{array}$ & 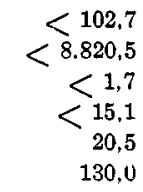 \\
\hline Pardinho & $\begin{array}{l}\text { Ma. } \\
\text { Mg. } \\
\text { Me. }\end{array}$ & $\begin{array}{l}\text { Mananciais } \\
\text { Bebedouros } \\
\text { Mananciais } \\
\text { Bebedouros } \\
\text { Mananciais } \\
\text { Bebedouros }\end{array}$ & $\begin{array}{r}<292,0 \\
<475,6 \\
<4,9 \\
<\begin{array}{r}11,7 \\
28,0 \\
140,0\end{array}\end{array}$ & $\begin{array}{r}272,6 \\
370.6 \\
<3,0 \\
<8,5 \\
28,0 \\
79,0\end{array}$ \\
\hline Itatinga & $\begin{array}{l}\text { Ma. } \\
\text { Mg. } \\
\text { Me. }\end{array}$ & $\begin{array}{l}\text { Mananciais } \\
\text { Bebedouros } \\
\text { Mananciais } \\
\text { Bebedouros } \\
\text { Mananciais } \\
\text { Bebedouros }\end{array}$ & $\begin{array}{r}81,8 \\
634,8 \\
3,0 \\
19,2 \\
34,0 \\
130,0\end{array}$ & $\begin{array}{r}33,7 \\
513,4 \\
-1,1 \\
11,1 \\
10,1 \\
95,0\end{array}$ \\
\hline
\end{tabular}

Ma. - Média aritmética

Mg. - Média geométrica

Me. - Mediana 
SOUZA, L.C. et al. Bactérias coliformes totais e coliformes de origem fecal em águas usadas na dessedentação de animaís. Rev. Saúde públ., S. Paulo, 17:112-22, 1983.

\section{T A B E L A 4}

Tipos e quantidades de mananciais e bebedouros analisados, segundo os municiplos visitados da regiăo de Botucatu, Sæo Paulo, 1974/75.

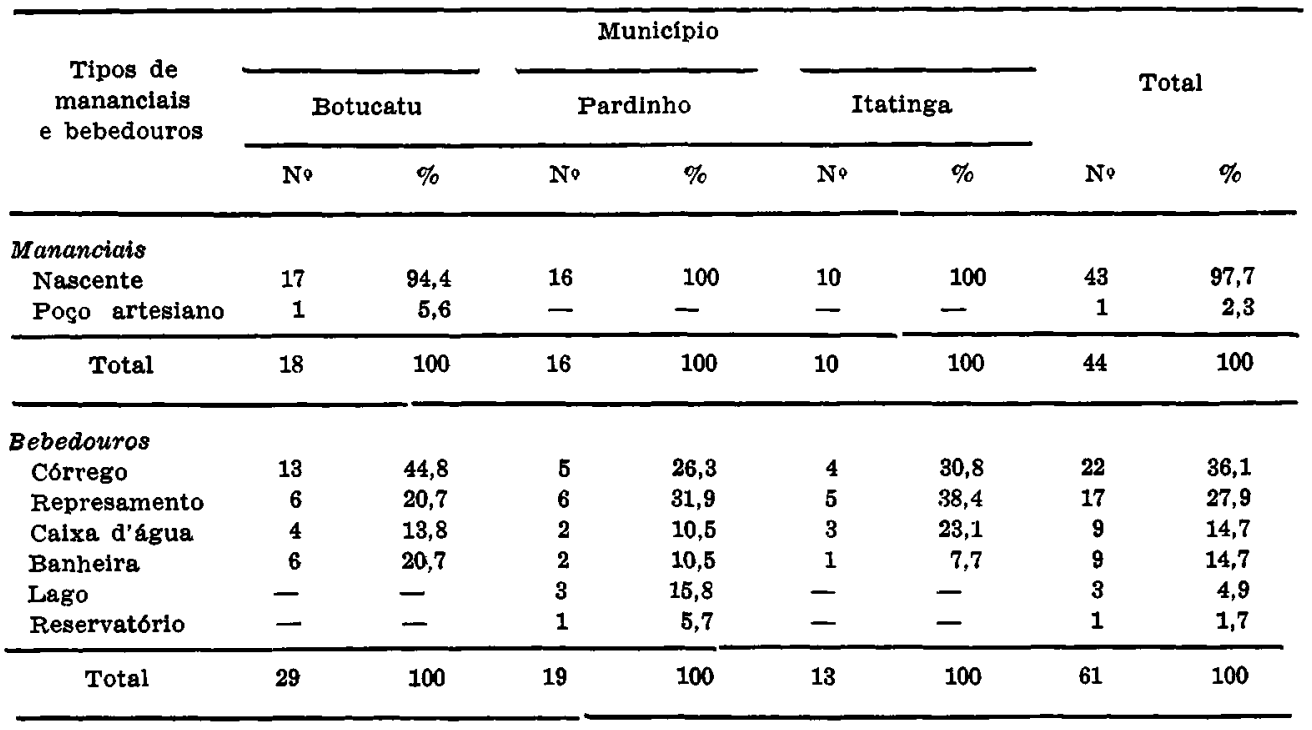

T A B E L A 5

Mananciais e bebedouros analisados, segundo a proteção e os municípios visitados da regiảo de Botucatu, São Paulo, 1974/75.

\begin{tabular}{|c|c|c|c|c|c|c|c|c|c|c|c|c|}
\hline \multirow{4}{*}{ Município } & \multicolumn{6}{|c|}{ Mananciais } & \multicolumn{6}{|c|}{ Bebedouros } \\
\hline & \multicolumn{4}{|c|}{ Protegidos } & & & \multicolumn{4}{|c|}{ Protegidos } & \multirow{2}{*}{\multicolumn{2}{|c|}{ Total }} \\
\hline & \multicolumn{2}{|c|}{ Sim } & \multicolumn{2}{|c|}{ Não } & \multicolumn{2}{|c|}{ Total } & \multicolumn{2}{|c|}{ Sim } & \multicolumn{2}{|c|}{ Năo } & & \\
\hline & No & $\%$ & No & $\%$ & No & $\%$ & $\mathbf{N}^{0}$ & $\%$ & No & $\%$ & No & $\%$ \\
\hline Botucatu & 1 & 5,6 & 17 & 94,4 & 18 & 100 & - & - & 29 & 100 & 29 & 100 \\
\hline Pardinho & - & - & 10 & 100 & 10 & 100 & 3 & 23,1 & 10 & 76,9 & 13 & 100 \\
\hline Itatinga & - & - & 16 & 100 & 16 & 100 & 4 & 21,1 & 15 & 78,9 & 19 & 100 \\
\hline Total & 1 & 2,3 & 43 & 97,7 & 44 & 100 & 7 & 11,5 & 54 & 88,5 & 61 & 100 \\
\hline
\end{tabular}

$\mathrm{Na}$ Tabela 3 estão distribuidas as médias aritmética e geométrica e as medianas dos NPM de coliformes totais e fecais, relativamente a mananciais e bebedouros, segundo os municípios visitados.

A Tabela 4 mostra a distribuição dos tipos de mananciais e bebedouros estudados, segundo os municípios visitados. Dos 44 mananciais, $43(97,7 \%$ ) eram do tipo nascente e $1(2,3 \%)$ do tipo artesiano. Dos 61 bebedouros, 22(36,1\%) eram córregos, $17(27,9 \%)$ represamentos, $9(14,7 \%)$ caixas d'água, $9(14,7 \%)$ banheiras, $3(4,9 \%)$ lagos e um reservatório. 
SOUZA, L.C. et al. Bactérias coliformes totais e coliformes de origem fecal em águas usadas na dessedentação de animais. Rev. Saúde públ., S. Paulo, 17:112-22, 1983.

$\mathrm{Na}$ Tabela 5 encontram-se distribuídos os mananciais e os bebedouros, relativamente a proteção e segundo os municípios visitados. Dos 44 mananciais e dos 61 bebedouros, $43(97,7 \%)$ e $54(88,5 \%)$, respectivamente, mostraram-se não protegidos.

\section{DISCUSSAOO}

Considerando-se que a Portaria GM $0013^{23}$ de 1976 estabelece parâmetros microbiológicos para mananciais, mas não para bebedouros, adotaram-se com relação a estes últimos, os mesmos valores estabelecidos para os primeiros. Porém, com respeito a este aspecto, é oportuno lavantar-se a questão sobre a viabilidade de se fazer esta distinção entre parâmetros para mananciais e para bebedouros. Deve-se ressaltar, também, o fato de que se colheram amostras de cada propriedade apenas em uma ocasião e não 5 amostras mensais como refere 0 Padrão Federal ${ }^{23}$, ou 5 amostras colhidas num periodo de até cinco semanas consecutivas, de acordo com o Padrão do Estado de São Paulo ${ }^{10}$.

Analisando-se a Tabela 1, pode-se observar que das 105 amostras examinadas, todas as obtidas a partir de mananciais apresentaram-se dentro do padrão vigente. O referido padrão tolera, em relação ao NMP/100 $\mathrm{ml}$, no máximo 20.000 coliformes totais $\mathrm{e}$ até 4.000 coliformes de origem fecal. Por outro lado, das amostras de bebedouros, com relaçāo a coliformes totais, $3(4,9 \%)$ apresentaram-se fora do padrão, e relativamente aos coliformes de origem fecal $6(9,8 \%)$ amostras mostraram-se com valores fora dos parâmetros legais.

Pode-se verificar, também, que dos 44 mananciais nenhum se revelou com NMP de coliformes totais e fecais acima dos limites estabelecidos, enquanto que das 29 amostras de água de bebedouros de Botucatu, apenas $3(10,3 \%)$ tiveram seu NMP fora dos parâmetros, tanto para coliformes totais como para fecais, e somente $2(6,9 \%)$ com NMP fora dos limites para coliformes fecais. No município de Pardinho, nenhuma das amostras analisadas apresentou NMP destas bactérias elevado, enquanto que, em Itatinga, apenas uma amostra de água de bebedouro mostrou-se acima do limite.

$\mathrm{Na}$ Tabela 2, com relação aos mananciais, pode-se verificar que os valores obtidos não ultrapassaram os limites estabelecidos pelo Padrão Federal ${ }^{23}$, pois houve variação de $<2$ a $3.300 / 100 \mathrm{ml}$ de água, para ambos os indicadores, mostrando que estes mananciais se revelaram, aparentemente, sem poluição acentuada de origem fecal.

Com relação aos bebedouros, ainda na Tabela 2, verifica-se que no municipio de Botucatu houve grande variação, ou seja, de $<2$ a 170.000 relativos aos NMP de coliformes totais e fecais. Porém, ao se analisar os valores obtidos (Tabela 1), observa-se que dos 29 bebedouros apenas $5(17,2 \%)$ ultrapassaram os limites estabelecidos pelo Padrão Federal ${ }^{23}$, se utilizados os mesmos valores referentes aos mananciais. Para as amostras colhidas em propriedades do município de Pardinho, as variações dos NMP de coliformes totais e fecais foram pequenas, ou seja de $<2$ a 3.500 e $<2$ a 2.800 , respectivamente. No de Itatinga, para os 19 bebedouros estudados, a variação foi de 17 a 4.900 para coliformes e de 11 a 4.900 para coliformes fecais (Tabelas 1 e 2 ), porém, somente um $(5,3 \%)$ apresentou NMPs elevados (Tabela 1).

$\mathrm{Na}$ Tabela 3 verifica-se que as médias aritméticas dos NMP de coliformes totais variaram de 81,8 a $<292$, e de coliformes fecais de $<33,7$ a $<276,6$ para mananciais, enquanto que para os bebedouros, tais variações foram maiores, ou seja, respectivamente, de $<475$ a $<10.156,9$ e de $<370,6$ a $<8.820,5$. Por outro lado, as médias geométricas dos NMP variaram de $<2,2$ a $<4,9$ para coliformes, e de $<1,1$ a $<3,0 \mathrm{em}$ mananciais e de $<11,7$ a $<21,5$ e de $<8,5$ a $<15,1$, respectivamente, em bebedouros. Nesta mesma Tabela, encontram-se distribuidas as medianas dos NMP de coliformes totais e fecais em relação aos mananciais e bebedouros das propriedades de criação 
SOUZA, L.C. et al. Bactérias coliformes totais e collformes de origem fecal em águas usadas na dessedentação de animais. Rev. Saúde públ., S. Paulo, 17:112-22, 1983.

de animais dos três municípios visitados. Para mananciais, as medianas dos NMP foram, para coliformes totais e fecais, respectivamente, de 20,5 para Botucatu, de 28 coliformes e 28 coliformes fecais para Pardinho, e de, respectivamente, 34 e 10,1 para ltatinga. Em relação aos bebedouros, tais valores foram de 170 coliformes e 130 coliformes fecais para Botucatu, de 140 e 79 para Pardinho e de 130 e 95 para Itatinga.

Vianna e col.27 (1975), trabalhands com 80 amostras de diferentes tipos de fontes de água provenientes de granjas avicolas do Estado de Minas Gerais, obtiveram em relação as NMP de coliformes por $100 \mathrm{ml}$ de água, as seguintes amplitudes de variação e medianas no teste confirmatório: a) variação de zero a 2.400 (poço raso), zero a 3.500 (poço arteziano), zero a 2.400 (nascente) e zero a $>2.400$ (córrego, rio e lagoa); b) medianas de 280 (poço raso), 79 (poço arteziano), 730 (nascente) e 2.400 (córrego, rio e lagoa).

Analisando-se a Tabela 4 , observa-se predominância do uso de mananciais do tipo nascente $(97,7 \%)$, sendo considerados como tal os que se originavam de encostas ou entre pedras. Somente em uma propriedade entre as visitadas o manancial utilizado era poço arteziano. Por outro lado, nesta mesma Tabela observa-se uma grande diversidade nos tipos de bebedouros utilizados, tais como, córregos, represamentos, caixas d'água, banheiras, lagos e reservatórios. Os córregos $(36,1 \%)$ e os represamentos $(27,9 \%)$ eram os tipos mais usados, mostrando que não há, ainda, de uma forma geral, preocupação em proteger a água destinada à dessedentação de animais.

Observando-se a Tabela 5, nota-se o pouco cuidado que, geralmente, se toma com relação à proteção dos mananciais e é importante salientar que, muitas vezes, a popula- ção humana do meio rural utiliza água de mananciais que são usados na dessedentação de animais. Ainda nesta Tabela, pode-se constatar que dos 61 bebedouros, dos quais foram coletadas amostras de água, $54(88,5 \%)$ não contavam com nenhuma proteção, demonstrando também que os cuidados dispensados à água fornecida aos animais são deficientes.

\section{CONCLUSOES}

1. Levando-se em conta o Padrão Federal que classifica as águas interiores do Território Nacional, apenas $3(4,9 \%)$ amostras de bebedouros, com relação a coliformes totais, apresentaram-se fora dos parâmetros, e relativamente a coliformes fecais, $6(9,8 \%)$ amostras tiveram seu NMP acima dos parâmetros estabelecidos.

2. Dos mananciais estudados, nenhum apresentou-se com NMP de coliformes totais e fecais acima dos limites estabelecidos, apesar de $43(97,7 \%)$ deles apresentarem-se sem nenhuma proteção.

3. Observou-se uma grande variedade do que foi utilizado como bebedouro, sendo que uma alta percentagem $(88,5)$ apresentou-se sem nenhuma proteção.

4. Considerando-se que o Padrão Federal vigente não faz distinçâo entre manancial e bebedouro, uma sugestão pode ser feita, ou seja, de que sejam estabelecidos padrões também para bebedouros, no tocante à dessedentação de animais.

5. As condições sanitárias das águas utilizadas pelos animais revelaram-se de boa qualidade, exceto em $6(9,8 \%)$ amostras de bebedouros em relação aos coliformes fecais e $3(4,9 \%)$ amostras quanto aos coliformes totais. 
SOUZA, L.C. et al. Bacterias coliformes totais e coliformes de origem fecal em águas usadas na dessedentação de animais. Rev. Saúde pübl., S. Paulo, 17:112-22, 1983.

SOUZA, L. C. et al. [Total and fecal coliform bacteria in animal drinking water]. Rev. Saúde públ., S. Paulo, 17:112-22, 1983.

ABSTRACT: The objective of the present experiment was to get information on the sanitary quality of water drunk by animals in the Botucatu region, S. Paulo State, Brazil. MPN (More Provable Number) counts of coliform and fecal coliform bacteria of 105 water samples were made. Of these samples 44 were taken from fountains and 61 from watering troughs. According to the Brazilian government directive, of the Ministry of the Interior, the 44 fountains were shown to be in accordance with the established parameters. As this government directive does not make reference to watering troughs, applying the same values established for fountains, it was observed that of 61 of the samples examined, only $6(9.8 \%)$ proved to be outside the parameters. Of the 105 samples examined, all showed good sanitary conditions, except 6 samples $(9.8 \%)$ of watering troughs in relation to fecal coliforms. Of these 6 samples, 3 showed bad sanitary conditions too, but only regard to total coliforms.

UNITERMS: Water. Waterning place. Coliforms. Fecal coliforms.

\section{REFERENCIAS BIBLIOGRAFICAS}

1. AMERICAN PUBLIC HEALTH ASSOCIATION. Standard methods for the examination of water and wastewater. 13 th ed. New York, 1971

2. ASSUmpÇão, L. Pesquisa de bactérias do gênero salmonella em carcaças e seus derivados vendidos a retalho. Arq. Fac. Hig., S. Paulo, 11:473-86, 1946.

3. BLOOD, D.C. \& HENDERSON, J.A. Medicina veterinária. $3^{\text {a }}$ ed. México, Editorial Interamericana, 1969.

4. BRANCO, S.M. As águas e os microryanismos: amebas, bactérias, e vírus. Presença nas águas naturais, nas águas poluídas e nas águas residuárias. In: Secretaria dos Serviços e Obras Públicas. Desinfecção de aguas. São Paulo, CETESB, 1974. cap. 1, p. 1-4.

5. BRANCO, S.M. Caracteristicas naturais da água: conceito de padrões de qualidade e potabilidade. In: Ágla: qualidade, padrões de potabilidade e poluição. Săo Paulo, CETESB, 1974. cap. 4, p. 31-42.

6. Christovao, D.A. Padrões bacteriológicos. In: Agua: qualidade, padrões de potabilidade e poluição. São Paulo, CETESB, 1974. cap. 6, p. 51-118.
7. CHRISTOVAO, D.A. et al. Condiçóes sanitárias de águas de irrigação de hortas do Município de São Paulo. I. Determinação da intensidade de poluição fecal através do NMP de coliformes e de $E$. coli. Rev. Saride públ., S. Paulo, 1:3-11, 1967.

8. ChristovaO, D.A. et al. Condições sanitárias de águas de irrigação de hortas no Municipio de Șăo Paulo. II. Isolamento de virus entéricos. Rev. Saúde públ., S. Paulo, 1:12-7, 1967.

9. Costa, A. et al. Estudo da poluição fecal em córregos de Ribeirão Preto, S. Paulo, através da determinação do NMP de coliformes e de Escherichia coli. In: Jornada Farmacêtica, 4", Ribeirão Preto, 1972. Resumos. Ribeirão Preto, 1972. p. 29-30.

10. DECRETO 8.468, de 8/9/1976: Classificação das águas interiores situadas no Território do Estado de São Paulo. Diario Oficial do Estado, S. Parlo, 9 set. 1976. p. 4-18.

11. DIESCH, S.L. Transmission de enfermedades por organismos hidricos de origem animal. Bol. Ofic. sanit. panamer., 69:314$-30,1970$.

12. DIKSTRA, R.R. Higiene animal y prevencion de enfermedades. Barcelona, Edit. Labor, 1970 . 
SOUZA, L.C. et al. Bactérlas coliformes totais e collformes de origem fecal em águas usadas na dessedentagazo de animais. Rev. Saúde públ., S. Paulo, 17:112-22, 1983.

13. GELDREICH, E.E. Aspectos microbiológicos dos esgotos e dos seus processos de tratamento. In: Secretaria dos Serviços e Obras Públicas. Desinfeção das aguas. Sáo Paulo, CETESB. 1974. cap. 10, p. 115-34.

14. GELDREICH, E.E. Qualidade microblológica em águas potáveis. In: Secretaria dos Serviços e Obras Públicas. Desinfec. codo das aguas. Săo Pa:-lo, CETESB, 1974, cap. 7 , p. $73-93$.

15. GIORGI, W. Animais domésticos como $\mathrm{p}$ ) tadores de salmonelas: significado epidemíológico e sua relação com a saúde pública. São Paulo, 1972. [Tese de Doutorado - Instituto de Ciencias Biomédicas da USP].

16. HIPOLITO, O. \& FREITAS, M.G. Doengas infecto-contagiosas dos animais domés. ticos. $3^{*}$ ed. Săo Paulo, Melhoramentos, 1963.

17. IARIA, S.T. et al. Contaminação do quibe cru vendido na zona central da Cidade de São Paulo, por microrganismos de origem fecal. Arq. F'ac. Hig., S. Paulo, 19:112-21, 1965.

18. MANUAL MERCK de Veterinária. Rahway. MERCK \& Co., 1970.

19. MARZOCHI, M.C.A. Estudos dos fatores envolvidos na disseminação de enteroparasitas. I. Estudo da poluição por cistos e ovos de enteroparasitas em córregos da Cidade de Ribeirão Preto, São Paulo. Rev. Inst. Med, trop. S. Paulo, 12:249-68, 1970.

20. MERCHANT, L.A. \& PARKER, R.A. Bact, riologia y virologia veterinaria. $3^{\mathrm{a}}$ ed. Zaragoza, Editorial Acribia, 1970.
21. MOREIRA, S. et al. Condiciones sanitarias del agia utilizada en granjas lecheras en un município en el Brasil. Bol. Ofic. sanit. panamer., 75:450-1, 1973.

22. PESTANA, B.R. \& RUGAI, E. O porco normal como portador de salmonelas. Rev. Inst. Adolfo Lutz, S. Paulo, 3:232-5, 1943.

23. PORTARIA GM/0013/15/jan/1976: Classificação das águas interiores do território nacional. Brasilia, Ed. Brasiliana, 1976. (Publ. 05/76).

24. SATAKE, $T$. et al. Estudo das condiçöes sanitárias das águas de irrigação hortas do municipio de Ribeirão Preto, São Paulo, por meio da determinação do número mais provável do grupo coliforme e de E. coli. Rev. Frac. Farm. Odont. Ribeirdo Preto, 13:11-22, 1976.

25. SCHWABE, C.W. Veterinary medicine and human health. 2 nd ed. Baltimore, William \& Wilkins, 1969.

26. TEMPLETON, G.S. Alimentos y alimentación. In: Templeton, G.S. Cria del conejo domestico. Mexico, Edit. Continental, 1968. p. 59-81.

27. VIANA, F.C. et al. Qualidade bacteriológica das águas de granjas avicolas do Estado de Minas Gerais: 1973. Arq. Eso. Vet. UFMG, $27: 119-24,1975$.

28. VON DER AA, R. Higiene veterinaria moderna. Zaragoza, Edit. Acribia, 1971.

Recebido para publicação em 22/09/1982

Aprovado para publicaşão em 17/12/1988 